\title{
The variability of the subantarctic front and the Southern Hemisphere atmospheric jet
}

\author{
João L. E. Simon ${ }^{1 *}$, Regina R. Rodrigues ${ }^{1}$
}

\author{
${ }^{1}$ Universidade Federal de Santa Catarina, Department of Oceanography \\ (R. João Pio Duarte Silva, 241 - Córrego Grande, Florianópolis - SC, 88037-000 - Brazil) \\ *Corresponding author: jl.simon@hotmail.com
}

\begin{abstract}
The latitudinal variations of the Subantarctic Front (SAF) and Southern Hemisphere atmospheric jet were investigated for the period of 1993-2016. Zonal wind velocity, sea surface height and temperature data were used to identify these features over the South Atlantic, South Pacific and Indian Oceans individually. During this period, the atmospheric jet migrated poleward $0.34^{\circ} \mathrm{S} \mathrm{decade}^{-1}$ in the Atlantic, $0.28^{\circ} \mathrm{S}$ decade $^{-1}$ in the Pacific and $0.14^{\circ} \mathrm{S}$ decade $^{-1}$ in the Indian oceans. Previous works have shown that the poleward trend is due to the expansion of the tropical belt as a consequence of greenhouse gas increase and cooling of polar stratosphere due to ozone depletion. In addition the atmospheric jet strengthen in all three basins. The SAF represents the Antarctic Circumpolar Current northern boundary and was observed in average at $46.3^{\circ} \mathrm{S}\left( \pm 0.5^{\circ}\right)$ in the Atlantic, $54.3^{\circ} \mathrm{S}\left( \pm 0.3^{\circ}\right)$ in the Pacific and $46.6^{\circ} \mathrm{S}\left( \pm 0.5^{\circ}\right)$ in Indian Oceans. The SAF shows a poleward migration of $0.46^{\circ} \mathrm{S}$ decade $^{-1}$ in the Atlantic, $0.20^{\circ} \mathrm{S} \mathrm{decade}^{-1}$ in the Pacific and $0.27^{\circ} \mathrm{S} \mathrm{decade}^{-1}$ in the Indian Oceans, which is attributed to the sea level increasing in the Southern Hemisphere due to thermal expansion. The SAF poleward trend is consistent with the positive trend of the Southern Annular Mode during the studied period. Moreover, the jet position is statistically significant correlated to the SAF position in each ocean basin. However, the coefficients are weak: +0.22 for the Atlantic, +0.17 for the Pacific and +0.21 for the Indian oceans. The latitudinal displacement of the SAF in the Pacific is inversely proportional to the El Niño-Southern Oscillations (ENSO). During El Niño years the SAF tend to be more poleward and during La Niña years more equatorward, with maximum correlation of 0.56 , with ENSO leading by three months.
\end{abstract}

Descriptors: Subantarctic front, Atmospheric jet, Southern hemisphere.

\section{INTRODUCTION}

The large-scale circulation of the Southern Hemisphere has two major features that greatly influence its climate. These features are known as the Antarctic Circumpolar Current (ACC) on the ocean and the Tropospheric Jet Stream (TJS) on the atmosphere (Hansen et al., 1984; Toggweiler and Russell, 2008; Eichelberger and Hartmann, 2007). Jet streams are bands of strong westerly winds that circulate the globe at the tropospheric level of the atmosphere in both hemispheres, usually located at mid latitudes. They are formed by the westerly deflection

Submitted on: 6/March/2019

Approved on: 7/October/2019

http://dx.doi.org/10.1590/S1679-87592019025606712

Editor: Edmo J. D. Campos of wind direction caused by the poleward movement of the air masses at the upper level of the Hadley cell, which causes a westerly air flux at the mid latitude end of the cell. Jets are also formed on mid latitude transient eddies by the sharp thermal gradient between warm tropical and cold polar winds (Holton, 1992; Bluestein, 1993). The jets are named by this difference in the formation mechanism, as Subtropical and Polar Jet, although they often occupy the same locations, making the distinction difficult. The jets have an important contribution to the hemisphere's climate as the position of storm tracks is often anchored on the equatorward limit of the jet. Synoptic scale disturbances are formed on the maximum wind speed location and migrate to lower latitude bringing storms along with (Holton, 1992). The presence of jets is characterized by strong winds, which cause turbulence on the jet's region 
and prevent hurricane formation, as they require lowsheer atmosphere regions (Gray, 1968; Vecchi and Soden, 2007). The small proportion of continents in the Southern Hemisphere allows a continuous TJS, while in the North Hemisphere the landmasses limit the jet's passage.

As the jet stream in the atmosphere, the ACC is the strongest and longest oceanic current in the globe. It has a transport of approximately $173 \mathrm{~Sv}\left(1 \mathrm{~Sv}=\times 10^{6} \mathrm{~m}^{3} \mathrm{~s}^{-1}\right.$; Donohue et al., 2016), surrounding the Antarctic continent in its full extension. It is the only current not to be limited by the presence of continents and is the dominant dynamic feature of the Southern Ocean. The current is generated by the combination of large-scale oceanic circulation and the strong westerly winds of the region (Trenberth et al., 1990; Cunningham et al., 2003). The geographical position of the ACC is defined by the position of its fronts. Fronts are narrow areas that concentrate the current's water transport while occupying only about $20 \%$ of its width (Whitworth et al., 1982). These bands are zones of intense change in water proprieties, such as temperature and salinity (Dong et al., 2006), which causes a difference in the sea level between warm equatorward and cold poleward waters due to thermal expansion (Gill, 1982), and a nutrient gradient that is highly limiting to the species who habitat the region (Trull et al., 2001). Although many authors differ between which fronts better represent the ACC and how to locate them, the terminology first established by Emery (1977) and reviewed by Orsi et al. (1995) separates the ACC as, from north to south, in Subantarctic Front (SAF), Polar Front (PF), and South Antarctic Circumpolar Current Front (SACCF). The SAF is particularly important because is considered the northern limit of the ACC and Southern Ocean waters by the (IHO, 1953).

The climate of the Southern Hemisphere has experienced changes in the last decades. The most noticed and documented is the poleward shift of the TJS as a consequence of the expansion of the tropical belt due to the greenhouse gases increase and the cooling of the polar stratosphere due to ozone depletion (Randel and $\mathrm{Wu}$, 1999; Hu and Fu, 2007; Polvani et al., 2011; Swart and Fyfe, 2012; Polvani et al., 2013). While several studies have focused on the Southern Hemisphere winds, only a few have focused on the changes of the oceanic fronts and the ACC. Kim and Orsi (2014) showed that the ACC location in previous studies is closely related, despite different criteria adopted to define its position. The ACC fronts surrounded the Antarctic continent maintaining their latitude, except when limited by topographic features, such as plateaus, ridges and continents. Gille (2014) noticed a poleward displacement in sea surface height contours at the Antarctic Circumpolar Current's region that is consistent with a warming of the southern waters and this in turn may increase basal melting in regions where the current is closer to the Antarctic continent (Graham et al., 2012; Pritchard et al., 2012; de Boer et al., 2013).

Based on the aforementioned discussion the main objective of this study is to investigate the TJS and SAF latitudinal variation on the South Atlantic, Indian and Pacific Oceans individually. However, it has always been challenging to study these global features due to the lack of in situ data with spatial and temporal coverage, particularly in the ocean. More recently, satellites have provided higher spatial and temporal resolution data with global coverage allowing more detailed studies of the location of ocean currents and fronts (Belkin and O'Reilly, 2009; Sokolov and Rintoul, 2007). Though, remote sampled data still commonly lacks in situ validation of its results. New ways of collecting hydrographic data that are less expensive and timing consuming have advanced such as floats that collect data as they drift. The Argo program is the current biggest float data source, sampling vertically the water column collecting temperature, salinity and pressure data since 1997 (Roemmich and Gilson, 2009). The constantly growing float dataset can be used to identify ocean currents and fronts (Giglio and Johnson, 2015), even though it does not have the same temporal resolution as satellite data (Kim and Orsi, 2014). The second objective of this study is to develop a methodology to identify the position of the SAF combining satellite with float data.

\section{DATA AND METHODS}

The data used in this study to compute the latitudinal position of the jet was obtained from the European Centre for Medium-Range Weather Forecasts (ECMWF) ERAInterim reanalysis for the period of 1993-2016 with a spatial resolution of $0.75^{\circ} \times 0.75^{\circ}$ (Dee et al., 2011). Daily values are obtained by averaging the 6-hourly zonal wind data. The jet latitudinal position is computed according to Woollings et al. (2010). The zonal wind is first vertically averaged within 4 pressure levels $700 \mathrm{hPa}, 775 \mathrm{hPa}, 850$ $\mathrm{hPa}$ and $925 \mathrm{hPa}$ and then zonally averaged over three longitudinal sectors, the Atlantic sector $\left(67^{\circ} \mathrm{E}-20^{\circ} \mathrm{W}\right)$, Pacific sector $\left(146^{\circ} \mathrm{W}-67^{\circ} \mathrm{E}\right)$ and Indian sector $\left(20^{\circ} \mathrm{W}\right.$ $\left.-146^{\circ} \mathrm{W}\right)$, neglecting winds above $80^{\circ} \mathrm{S}$ and under $10^{\circ} \mathrm{S}$. The resulting zonal wind data are filtered by applying a 
low-pass 10-day Lanczos filter with a 61-day window (Duchon, 1979) to avoid high-frequency disturbances. The daily latitudinal position of the jet is then computed as the latitude of the maximum zonal wind (Figure 1) for each sector.

The Subantarctic Front defines the ACC northern limit. To find its position the contour-based method was employed using Sea Surface Height (SSH) data (Thompson and Sallee, 2012; Sallée et al., 2008; Orsi et al., 1995; Graham et al., 2012; Sokolov and Rintoul, 2009a). The absolute dynamic topography data, treated here as $\mathrm{SSH}$, was obtained by the Developing Use of Altimetry for Climate Studies (DUACS) and formerly distributed by Archiving, Validation, and Interpretation of Satellite Oceanographic data (AVISO), being made available now by the Copernicus Marine Environment Monitoring System (CMEMS, 2018). The data covers the period of 1993-2016 and was daily sampled with a spatial resolution of $0.25^{\circ} \times 0.25^{\circ}$. We used a methodology by Kim and Orsi (2014) to determine the SSH contour that best fits the SAF position for Scotia Sea region $\left(40^{\circ} \mathrm{S}-65^{\circ} \mathrm{S}, 70^{\circ} \mathrm{W}-40^{\circ} \mathrm{W}\right)$ for each time step using additional high quality hydrographic profiles (Figure 2). The hydrographic data were obtained from 20,022 profiles sampled within the Scotia Sea limits for the period of 2010-2017 by the International Argo Program, and distributed by the Global Ocean Data Assimilation Experiment (GODAE; Argo, 2000). The depth of sampling was calculated from the pressure and latitudinal position of each profile using UNESCO algorithm (Fofonoff and Millard, 1983). Only profiles flagged as good data by the Argo flag system (Argo, 2017) were

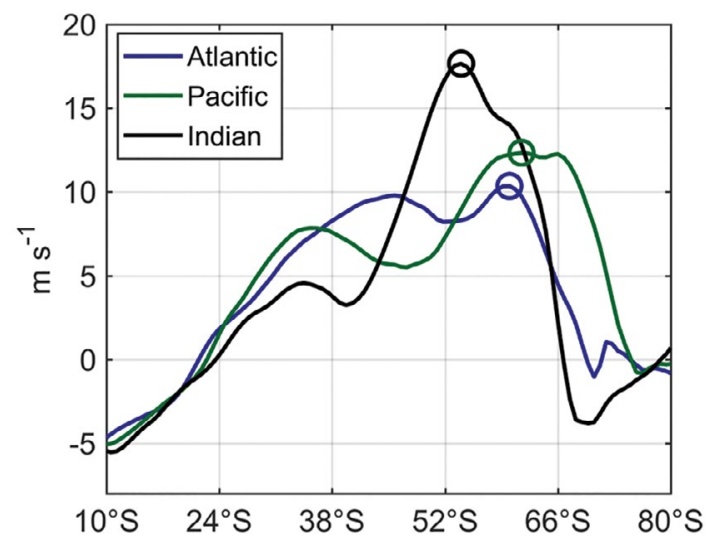

Figure 1. Zonally averaged wind speed $\left(\mathrm{m} \mathrm{s}^{-1}\right)$ after applying the Lanczos filter for the period of 1993-2016. The circles indicate the jet latitudinal position.

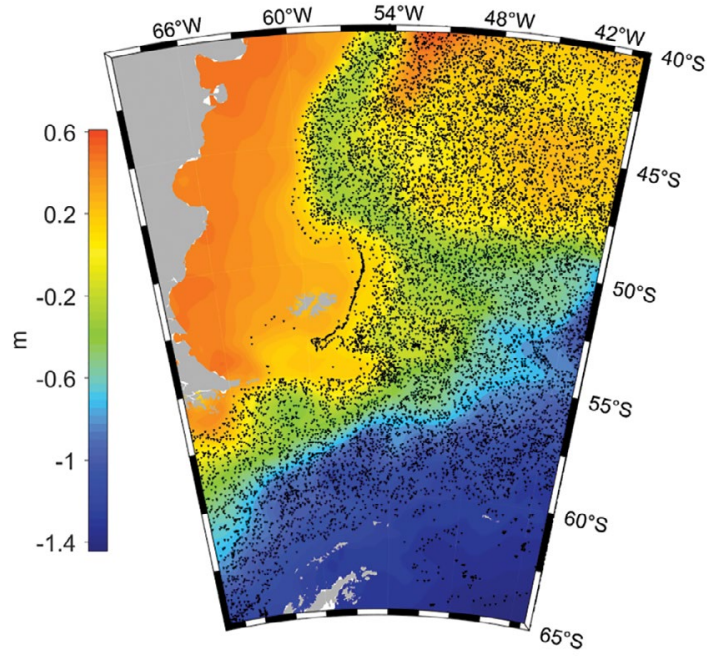

Figure 2. Sea surface height $(\mathrm{m})$ averaged over the Scotia Sea region and for the period of 1993-2016. The black dots represent the position of 20,022 Argo profiles from 2010 to 2017.

used. The profile data was linearly interpolated and checked with Pearson's correlation (Benesty et al., 2009), filtering out profiles that had a correlation lower than $90 \%$ $(p<0.05)$ with the original data. The interpolation set the vertical resolution of the temperature profiles to 1 meter and discarded samples shallower than $15 \mathrm{~m}$ or deeper than $1000 \mathrm{~m}$, only generating data between the first and last pressure levels sampled by each float. The area around Drake Passage was chosen to use the Argo floats to determine the SAF position due to its topography features. The bottleneck effect in this area limits the ACC position (Grahan et al., 2012) and forces the SAF to go north along the South America continental slope (Cunningham et al., 2003).

The daily SSH gridded data were time averaged and then zonally averaged along the longitudinal section for each ocean basin (Figure 3). The temperature profiles from Argo were grouped by year and averaged for the same grid boxes from the SSH data. This procedure was done for each depth level separately. The resulting temperature gridded data were zonally averaged within the Scotia Sea limits, then time averaged over the data period (Figure 4). Finally, the temperature data was vertically averaged (Figure 5) and compared with the zonally averaged $\mathrm{SSH}$ to find the northernmost region of fast declining on both SSH and temperature, which was accomplished by calculating the anomaly of the series and extracting the one dimension gradient. The temperature gradient was smoothed with a moving-average filter of $1.25^{\circ}$ window, 


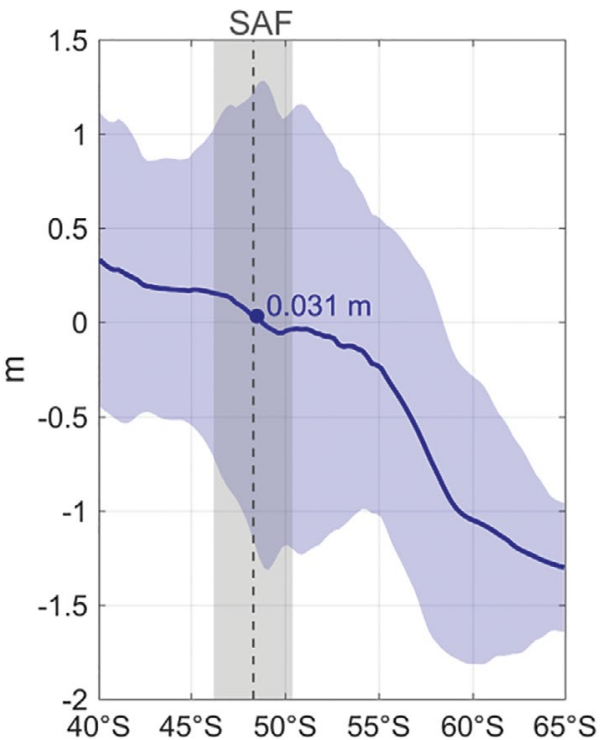

Figure 3. SSH (m, solid blue) averaged over the Scotia Sea area $\left(40^{\circ} \mathrm{S}-65^{\circ} \mathrm{S}, 70^{\circ} \mathrm{W}-40^{\circ} \mathrm{W}\right)$ for the period of $1993-2016$. Area shaded in blue shows the local standard deviation and in grey the SAF, dashed line shows the peak of the gradient.

and the latitudinal position of the northern peak in both gradients was extracted and used to find the corresponding value on the averaged SSH profile of the Scotia Sea.

The gradient profiles evidenced the two major transition sections, observed around $48^{\circ} \mathrm{S}$ and $57^{\circ} \mathrm{S}$ (Figure 6). The northern peak exhibited the highest temperature contrast between northern and southern portions, as well as the second highest contrast in $\mathrm{SSH}$, evidenced in the gray areas of Figures 3 and 5. The latitudinal position of these peaks (circled in red and blue) was used to find the associated $\mathrm{SSH}$ value, demonstrated by the intersection between dashed line and the SSH profile. The SSH value of $0.031 \mathrm{~m}$ was used for the front location on a global scale by drawing isometric contour lines in the daily SSH grids and filtering to retain only continuous lines surrounding the globe, which excluded false positives caused by interactions with rings. The latitudinal position of the remaining contour lines was extracted and reorganized in the original grid spatial resolution of $0.25^{\circ} \times 0.25^{\circ}$. The SAF daily position was obtained by verifying the gridded latitudinal interval most frequently occupied by the contour line in each ocean basin. Once the daily latitudinal position of both SAF and TJS were obtained for each sector, a linear trend was fitted to the data using the minimum least square method (Chatterjee et al., 2000) to verify any trend on the series.

To investigate the link between ENSO and SAF we use monthly NIINO3.4 data obtained from the Global Climate Observing System (GCOS) Working Group on Surface Pressure (WG-SP) for the period of 1993-2016 (Trenberth and Stepaniak, 2001). A Fourier analysis (Bracewell, 1966) was performed to extract the seasonal cycle from the SAF latitudinal position time series. Then, the SAF latitudinal position time series for the Pacific basin were detrended to performer the correlation analysis with the jet position and ENSO index.

\section{RESULTS}

The averaged zonal wind is presented in Figure 7. As expected, the higher velocities are concentrated in a belt between $40^{\circ} \mathrm{S}$ and $60^{\circ} \mathrm{S}$ surrounding the Antarctic continent. The Andes Mountain Range strongly limits the jet passage, forcing its pattern poleward on the southern region of South America. The highest wind speeds were found over the Indian Ocean, with an average of 13.0

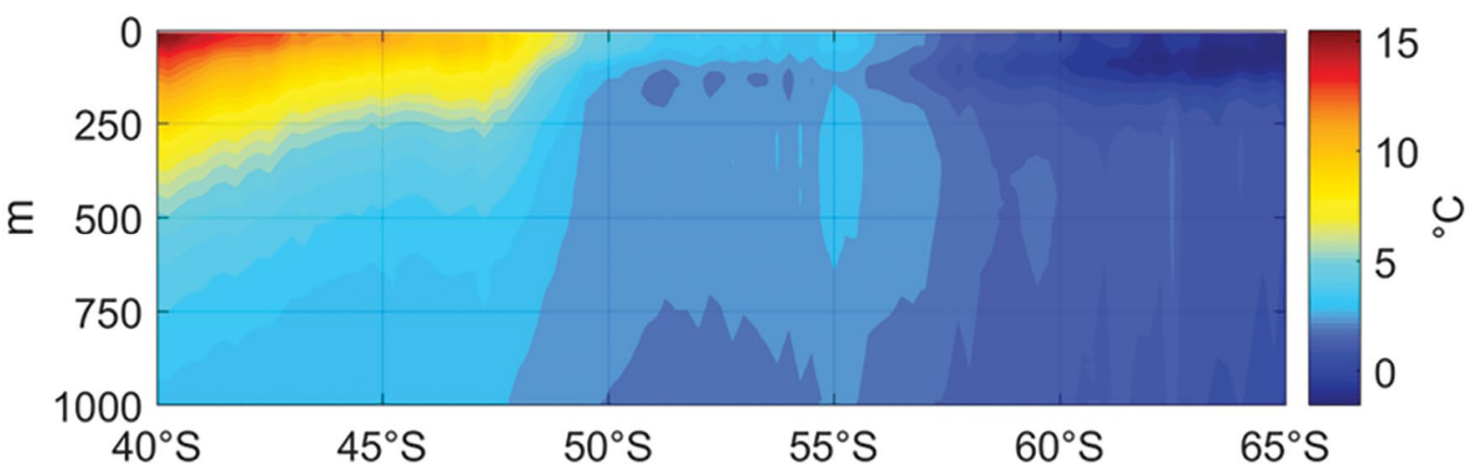

Figure 4. Zonal mean temperature $\left({ }^{\circ} \mathrm{C}\right)$ from Argo profiles averaged for the Scotia Sea region $\left(40^{\circ} \mathrm{S}-65^{\circ} \mathrm{S}, 70^{\circ} \mathrm{W}-40^{\circ} \mathrm{W}\right)$ and for the period of 2010-2017. 


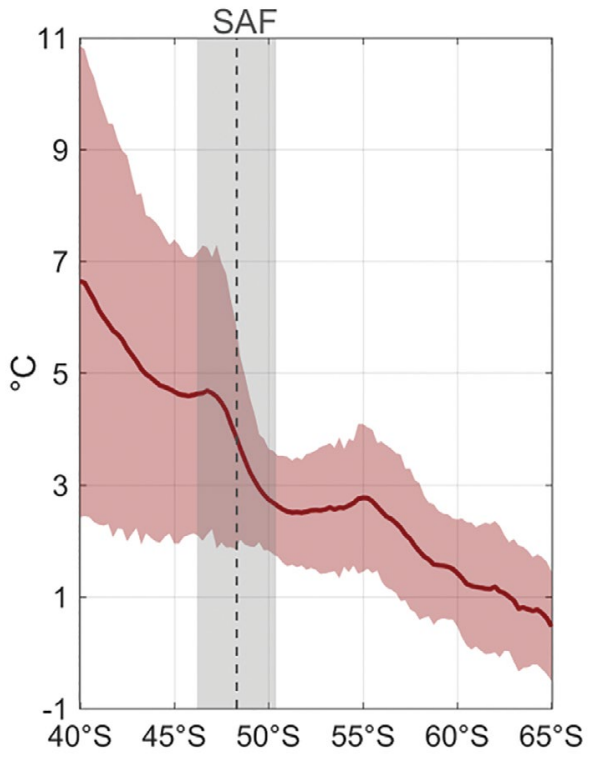

Figure 5. Temperature $\left({ }^{\circ} \mathrm{C}\right)$ from Argo data (solid red) averaged over the Scotia Sea area $\left(40^{\circ} \mathrm{S}-65^{\circ} \mathrm{S}, 70^{\circ} \mathrm{W}-40^{\circ} \mathrm{W}\right)$ and for the period of 2010-2017. Area shaded in red shows the local standard deviation and in grey the SAF, dashed line shows the peak of the gradient.

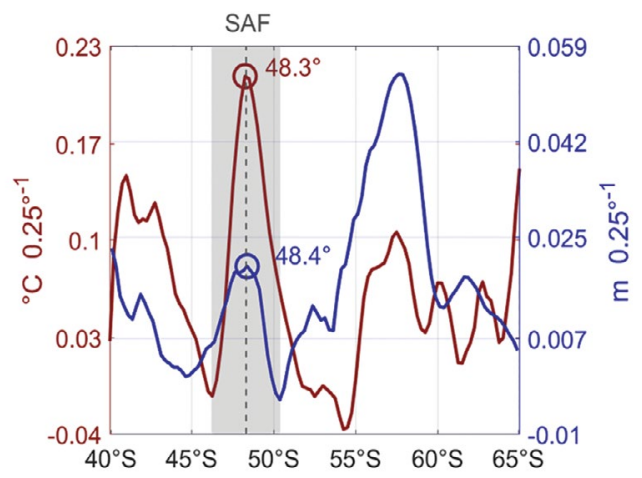

Figure 6. Gradients of sea temperature $\left({ }^{\circ} \mathrm{C}\right.$, red) and sea surface height $(\mathrm{m}$, blue) in Scotia Sea $\left(40^{\circ} \mathrm{S}-65^{\circ} \mathrm{S}, 70^{\circ} \mathrm{W}-40^{\circ} \mathrm{W}\right)$. Shaded gray area represents $\mathrm{SAF}$ and dashed line shows the peak in the gradient (circles).

$\mathrm{m} \mathrm{s}^{-1}( \pm 2.17)$. The Atlantic and Pacific present averaged winds of $11.0 \mathrm{~m} \mathrm{~s}^{-1}( \pm 1.88)$ and $9.93 \mathrm{~m} \mathrm{~s}^{-1}( \pm 2.09)$. The averaged jet latitudinal position was at $49.8^{\circ} \mathrm{S}( \pm 6.22)$ in the Atlantic, $54.2^{\circ} \mathrm{S}( \pm 6.67)$ in the Pacific and $49.1^{\circ} \mathrm{S}$ $( \pm 4.13)$ in the Indian. The TJS latitudinal position is known to be correlated to storm tracks, which are zones of cyclogenesis and storm formation that impact the climate on the Southern Hemisphere (Trenberth, 1991). The cyclone development on the Southern Hemisphere starts to happen between $35^{\circ} \mathrm{S}$ and $55^{\circ} \mathrm{S}$, exhibiting mature systems between $40^{\circ} \mathrm{S}$ and $60^{\circ} \mathrm{S}$ (Carleton, 1979). The jet's

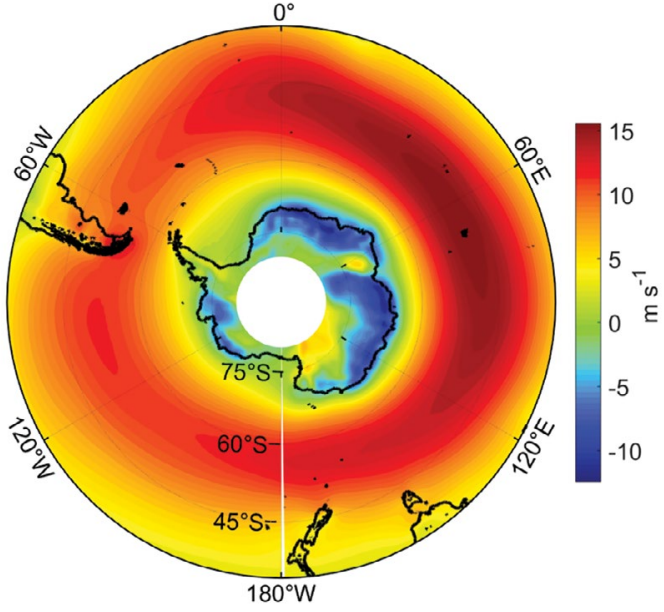

Figure 7. Map of zonal wind speed $\left(\mathrm{m} \mathrm{s}^{-1}\right)$ averaged for the period of 1993-2016 and between 700 and $925 \mathrm{hPa}$. Positive (negative) values represent winds from west (east).

position found in this study supports this claim, with the average position $\sim 50^{\circ} \mathrm{S}$ in the Atlantic and Indian sectors and $\sim 55^{\circ} \mathrm{S}$ in the Pacific (Figure 7). This $\sim 5^{\circ}$ difference in the jet's core latitudinal position between ocean basins was also observed by Trenberth et al. (1990). The jet core latitudinal position in each basin remains close to the observed by Nakamura and Shimpo (2004) and by Archer and Caldera (2008).

The time series of latitudinal position of the jet over the studied period is shown in Figure 8. Previous studies have already reported a global poleward shift of the jet (Randel and $\mathrm{Wu}, 1999 ; \mathrm{Hu}$ and $\mathrm{Fu}, 2007$; Polvani et al., 2011; Swart and Fyfe, 2012; Polvani et al., 2013). Our study investigates this migration individually for the three ocean basins. As for the global case, there is a negative trend (poleward shift) in all three ocean basins that are statistically significant, except for the Indian Ocean (Table 1). If one considers the trends for the period of 2000-2016, they are higher and statistically significant for all three ocean basins, but reverses the sign in the Pacific. This is probably due to the Interdecadal Pacific Oscillation (IPO) that reversed its sign from positive to negative in 2000, when the trade winds strengthening over the tropical Atlantic (England et al., 2014) and the tropical Pacific became cooler with more La Niñas. This is consistent with the idea that the expansion of the tropical belt due to global warming pushes the jet poleward but in the case of Pacific pushes the jet equatorward associated with cooling due to the natural variability of the IPO. 

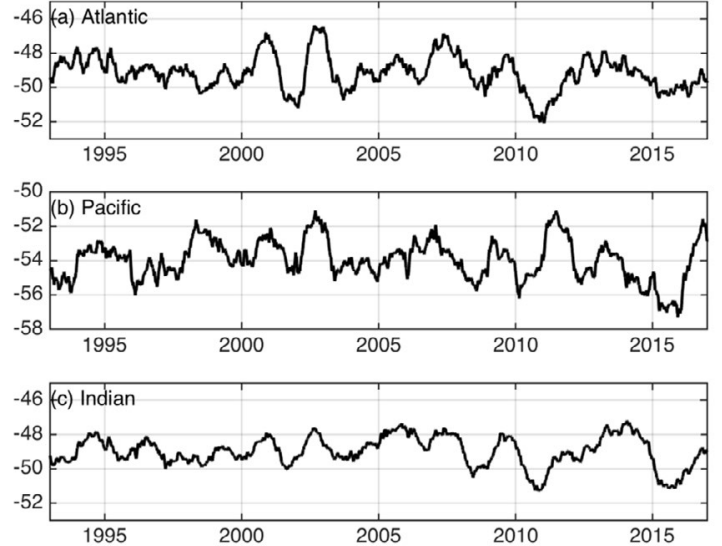

Figure 8. Time series of the jet latitudinal position $\left(^{\circ}\right)$ for (a) Atlantic $\left(10^{\circ} \mathrm{S}-80^{\circ} \mathrm{S}, 67^{\circ} \mathrm{E}-20^{\circ} \mathrm{W}\right)$, (b) Pacific $\left(10^{\circ} \mathrm{S}-80^{\circ} \mathrm{S}, 146^{\circ} \mathrm{W}-67^{\circ} \mathrm{E}\right)$ and (c) Indian $\left(10^{\circ} \mathrm{S}-80^{\circ} \mathrm{S}, 20^{\circ} \mathrm{W}-146^{\circ} \mathrm{W}\right)$ oceans.

Table 1. Trends per decade for the jet latitude, maximum jet velocity and SAF latitude. Trends statistically significant at $95 \%$ confidence level are displayed in bold using the nonparametric Mann-Kendall test.

\begin{tabular}{|c|c|c|}
\hline Trend (per decade) & $1993-2016$ & $2000-2016$ \\
\hline South Atlantic Jet Latitude & $-0.34^{\circ}$ & $-0.55^{\circ}$ \\
\hline South Pacific Jet Latitude & $-0.28^{\circ}$ & $+1.41^{\circ}$ \\
\hline South Indian Jet Latitude & $-0.14^{\circ}$ & $-1.42^{\circ}$ \\
\hline South Atlantic Jet Intensity & $+0.22 \mathrm{~m} / \mathrm{s}$ & $+0.02 \mathrm{~m} / \mathrm{s}$ \\
\hline South Pacific Jet Intensity & $+0.34 \mathrm{~m} / \mathrm{s}$ & $-0.67 \mathrm{~m} / \mathrm{s}$ \\
\hline South Indian Jet Intensity & $+0.14 \mathrm{~m} / \mathrm{s}$ & $+0.37 \mathrm{~m} / \mathrm{s}$ \\
\hline $\begin{array}{l}\text { South Atlantic SAF } \\
\text { Latitude }\end{array}$ & $-0.46^{\circ}$ & $-0.28^{\circ}$ \\
\hline South Pacific SAF Latitude & $-0.20^{\circ}$ & $-0.12^{\circ}$ \\
\hline South Indian SAF Latitude & $-0.27^{\circ}$ & $-0.19^{\circ}$ \\
\hline
\end{tabular}

The time series of maximum zonal velocity along the jet core is also computed and shown in Figure 9. Corroborated by the same previous studies, there is an intensification of the jet in all three ocean basins with the trends statistically significant (Table 1). Again when the trends are computed for the period of 2000-2016, there is a weakening of the jet over the Pacific due to the cooling of the tropical Pacific associated with negative phase of the IPO. This is consistent with the fact that the jet is a response to the meridional temperature gradient between the tropics and midlatidudes. The cooling of the Pacific weakens the temperature gradient and thus the jet.

Now we turn our attention to the SAF variability. The time averaged SSH for the period of 1993-2016 is shown in Figure 10. The sea surface height decreases poleward, and it is possible to observe lower heights in regions of
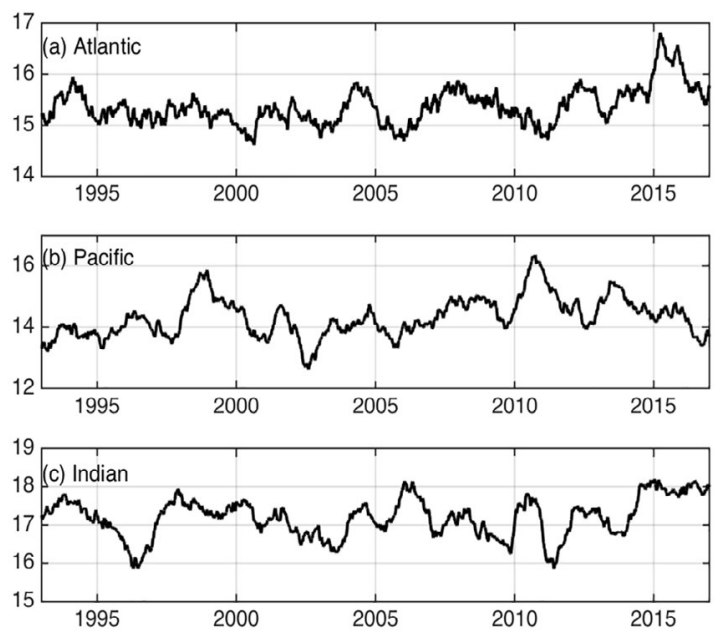

Figure 9. Time series of the maximum zonal velocity (m-1 s-1) along the core of the atmospheric jet for (a) Atlantic $\left(10^{\circ} \mathrm{S}-80^{\circ} \mathrm{S}\right.$, $\left.67^{\circ} \mathrm{E}-20^{\circ} \mathrm{W}\right)$, (b) Pacific $\left(10^{\circ} \mathrm{S}-80^{\circ} \mathrm{S}, 146^{\circ} \mathrm{W}-67^{\circ} \mathrm{E}\right)$ and (c) Indian $\left(10^{\circ} \mathrm{S}-80^{\circ} \mathrm{S}, 20^{\circ} \mathrm{W}-146^{\circ} \mathrm{W}\right)$ oceans.

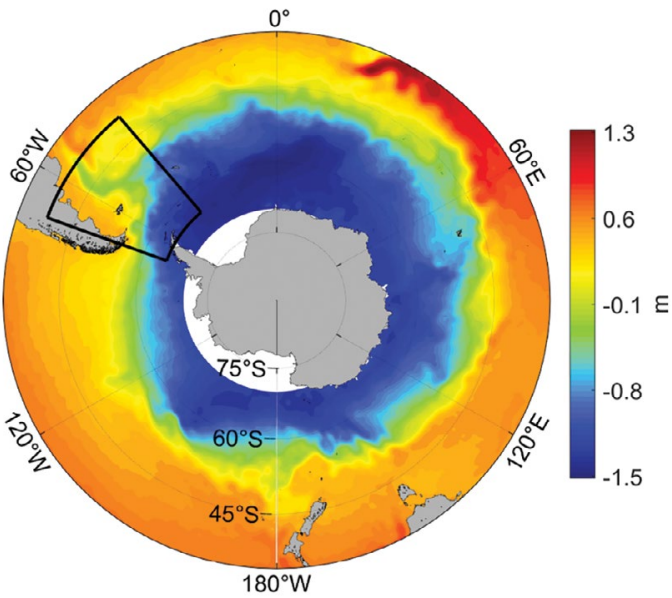

Figure 10. Map of Sea Surface Height (m) averaged for the period of 1993-2016. The black box displays the Scotia Sea area $\left(40^{\circ} \mathrm{S}-65^{\circ} \mathrm{S}\right.$, $\left.70^{\circ} \mathrm{W}-40^{\circ} \mathrm{W}\right)$ where the methodology with float data was applied.

colder water currents such as the Falkland Current, as well as higher heights in warmer water current such as the Agulhas Current. The contours follow topography features, and it is possible to notice elevations such as the Campbell Plateau in south New Zealand in the SSH mean map. Previous studies have used SSH data to determine the ACC frontal systems. For instance, applying a contour method on SSH fields, Sokolov and Rintoul (2009b) observe that fronts do not maintain a single-filament structure all around the Antarctic continent, but rather divide in two or more bands and remerge as the topography dictates. Chapman (2014) show, on the other hand, that single 
band contour applied in cumulative incidence on a global scale has the best noise/signal ratio of the common location methods (gradient method, probability density function method), which explains the similarities between the SAF geographical position found here and in Sokolov and Rintoul (2007, 2009b). Our results also agree well with Orsi et al. (1995) in the Pacific and Atlantic basins. Around South Australia, our results differs from Orsi et al. (1995) but agrees with Belkin and Gordon (1996), which is a more detailed study between South Africa and Tasmania. Our results are also similar to Sun and Watts (2002), who used a stream function method, for shallower regions such as the Campbell and Kerguelen Plateaus.

The SAF local frequency of occurrence reinforced the strong correlation between topography features and the ACC (Figure 11). Regions with shallower depths presented a strong anchorage of the SAF position and consequent high frequency of occurrence, hence the thinner lines (higher frequencies) at the southern South America continental slope. The SAF position is also limited poleward by the Kerguelen's Plateau, and equatorward by the Campbell Plateau. The front exhibited stability as well where it crossed mid-ocean ridges such as the Mid-Atlantic Ridge, Pacific Antarctic Ridge and Southeast Indian Ridge.
The time series of the SAF latitudinal position is shown in Figure 12 for the three ocean basins separately. The longterm linear trend shows the decadal poleward migration over the observed period for the Atlantic, Pacific and Indian oceans, however with different rates. The linear trend was $-0.46^{\circ} \mathrm{S}$ decade $^{-1}$ for the Atlantic, $-0.20^{\circ} \mathrm{S}$ decade $^{-1}$ for the Pacific and $-0.27^{\circ} \mathrm{S}$ decade $^{-1}$ for the Indian oceans (Table 1 ). This is similar to the results for the TSJ. The SAF poleward migration has been observed by Kim and Orsi (2014) and Gille (2014). Gille (2014) focuses on the ACC transport and showed that the transport does not follow the latitudinal migration observed from SSH contours, arguing that this migration may be related to large scale sea surface level changes occurring on the Southern Hemisphere rather than a regional current displacement. Although the SSH may not reflect a migration in the current transport, its geographical location is linked with other water proprieties, such as temperature, nutrients and density. The SAF poleward shift indicates warmer waters reaching farther south in the last decades, which threatens habitats of highly endemic Antarctic species (Trull et al., 2001). For this reason, it is important to monitor the SAF contour, even if does not represents the position of the ACC.

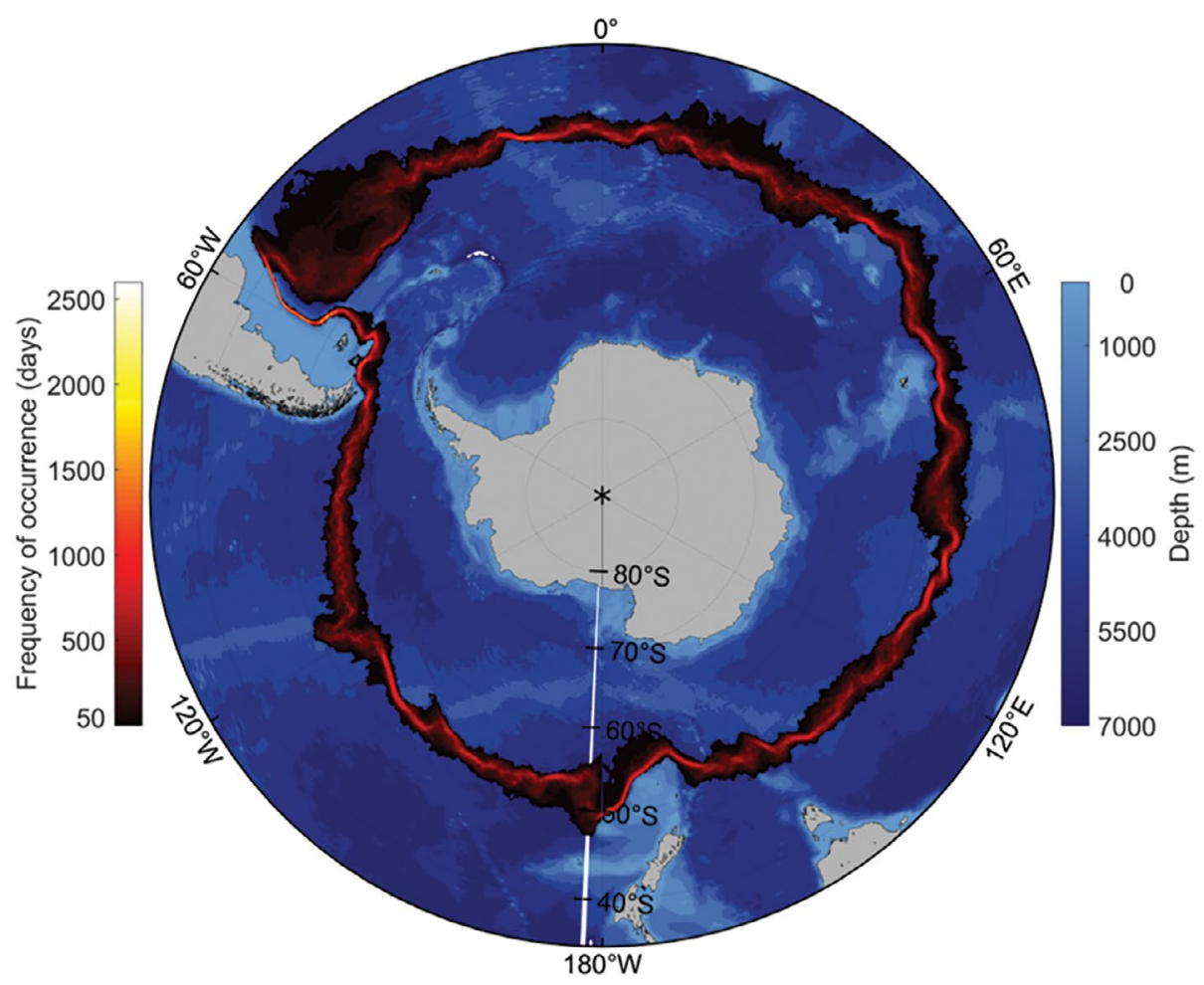

Figure 11. Map of the SAF geographical frequency of occurrence (days) for the period of 1993-2016 over topography. 

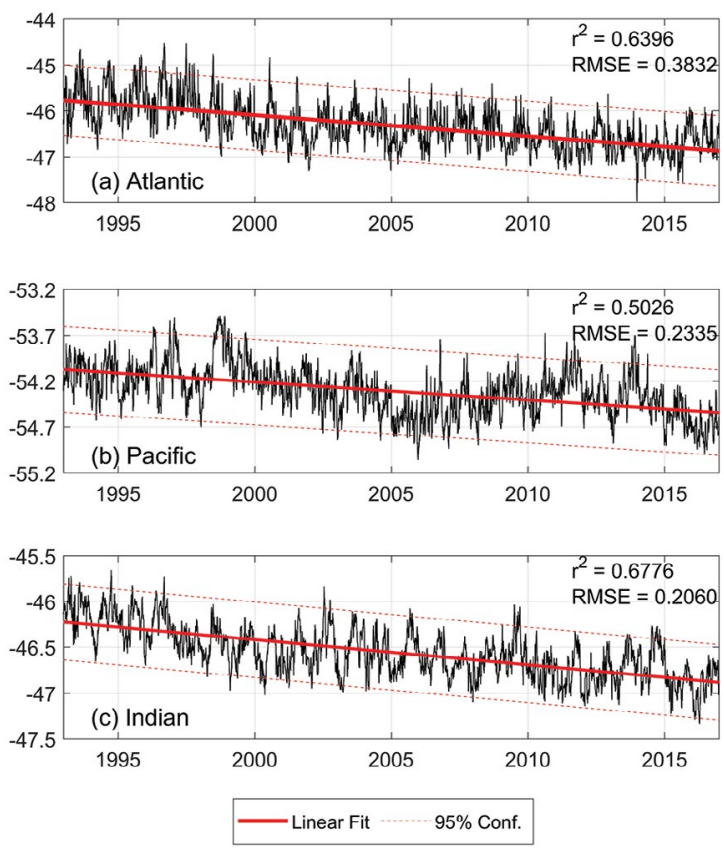

Figure 12. SAF daily (1993-2016) latitudinal position $\left({ }^{\circ}\right)$, zonally averaged over the (a) Atlantic $\left(10^{\circ} \mathrm{S}-80^{\circ} \mathrm{S}, 67^{\circ} \mathrm{E}-20^{\circ} \mathrm{W}\right)$, (b) Pacific $\left(10^{\circ} \mathrm{S}-80^{\circ} \mathrm{S}, 146^{\circ} \mathrm{W}-67^{\circ} \mathrm{E}\right)$ and (c) Indian $\left(10^{\circ} \mathrm{S}-80^{\circ} \mathrm{S}, 20^{\circ} \mathrm{W}-146^{\circ} \mathrm{W}\right)$ oceans. Solid red lines represent the best linear fit, with Pearson's correlation $\left(\mathrm{r}^{2}\right)$ and Root Mean Squared Error (RMSE) displayed on the top/right. Dashed red lines represent the $95 \%$ confidence interval.

As for the TJS, the Pacific SAF shows a different pattern from the other two ocean basins, which motivated a more detailed analysis of the signal to verify if the ENSO/IPO relationship was responsible for such pattern. Figure 13 shows the de-trended SAF latitudinal position for the Pacific and the reconstructed modeled data obtained from a Singular Value Decomposition analysis (Golub and Reinsch, 1970) using the most energetic frequencies found in the Fourier transformation, excluding the seasonal cycle. The reconstructed signal is then plotted against the ENSO index in Figure 14. A lagged cross-correlation analysis between the two series was performed and the maximum correlation of -0.56 occurs with ENSO leading for three months the SAF time series. The negative correlation means that during El Niño years the SAF tend to be more poleward and during La Niña years more equatorward. This is consistent with the jet position. When the tropical Pacific is cooler the jet is more equatorward and so thus the SAF. This result agrees with Sallé et al. (2008) and Kim and Orsi (2014).

Finally we perform a cross-correlation analysis between the TJS and SAF in each ocean basin. The maximum correlation occurs at zero lag and is +0.22 for the Atlantic,

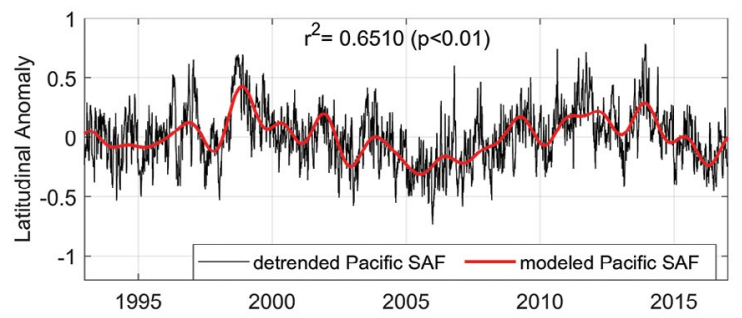

Figure 13. Daily Pacific SAF de-trended latitudinal anomaly and the reconstructed signal based on low-passed filtered series (red) for the period from 1993 to 2016. Pearson's correlation $\left(\mathrm{r}^{2}\right)$ and significance level (p) are displayed on top-center.

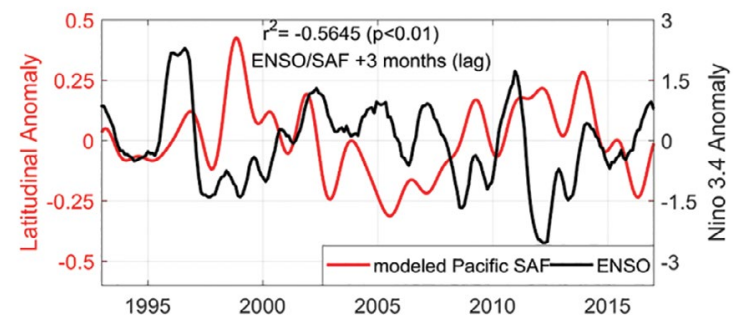

Figure 14. Pacific SAF (red) and ENSO (black) from 1993 to 2016. ENSO index is SST anomalies averaged within the NINO34 box $\left(120^{\circ} \mathrm{W}-170^{\circ} \mathrm{W}, 5^{\circ} \mathrm{N}-5^{\circ} \mathrm{S}\right)$. Pearson's correlation $\left(\mathrm{r}^{2}\right)$, significance level (p) and lag ratio are displayed on top-center.

+0.17 for the Pacific and +0.21 for the Indian oceans. The coefficients are statistically significant, albeit weak. Climate change tends to push the TJS and SAF poleward and this can bee seen through the long-term trends presented here. However, the interannual variability (correlation analysis) shows they might vary independently. The winds change the ocean circulation but the jet position can be anchored by frontal oceanic systems (Sinclair, 1995; O'Reilly and Czaja, 2015), especially over open water regions. The mean SAF position of $\sim 46^{\circ} \mathrm{S}$ for the Atlantic and Indian and $\sim 54^{\circ}$ for the Pacific reported here may play a role on the TJS location. The warming of Southern Ocean may be the key to understanding the poleward migration of $\mathrm{SSH}$ contours reported here (Hughes, 2000; Gille, 2008; Sutton and Roemmich, 2011). The higher temperatures increase the pressure difference between pole and mid-latitudes, intensifying the Southern Annular Mode (Thompson and Solomon, 2002). The warmer waters reach farther south, closer to Antarctic continent, increasing heat transport and promoting the basal melting and thinning of ice shelves in regions where the current is closer to the pole, i.e. the Amundsen and Bellingshausen seas (Pritchard et al., 2012; Paolo et al., 2015). 


\section{SUMMARY AND CONCLUSIONS}

We used multiple datasets to investigate two large-scale circulation features of the Southern Hemisphere. The zonal wind velocity data between 700 and $925 \mathrm{hPa}$ was used to track the TJS while temperature profiles from Argo floats and SSH from altimetry were used to identify the SAF. Both features were analyzed individually for the Atlantic, Pacific and Indian oceans.

The TJS presented a poleward migration and strengthening in the three oceans as previous studies have shown globally, particularly after 2000. The SAF also migrated poleward in the three oceans. This is consistent with warming of southern waters and the expansion of the tropical belt due to the increase of greenhouse gases and the cooling of the stratosphere due to ozone depletion, as suggested by previous works. The IPO and ENSO influence in the STJ and SAF position in the Pacific, pushing the both poleward during positive phases (El Niños) and equatorward during negative phases (La Niñas).

The future climate projections are expected to aggravate these trends and impact human life, by melting Antarctic ice, causing global sea level rising and coastal erosion (Church and White, 2011). The TJS and the ACC are key features to understand the Southern Hemisphere climate, although further research is required to discriminate the mechanisms that influence these features and their connection in future projections.

\section{ACKNOWLEDGEMENTS}

This work was supported by Instituto Nacional de Ciências e Tecnologia para Mudanças Climáticas (INCTMC Fase II) Grant\# 465501/2014-1 and by Coordenação de Aperfeiçoamento de Pessoal de Nivel Superior (CAPES) Grant\# 88887.136402/2017-00. This work is also part of the Programa de Pós Graduação em Oceanografia (PPGOceano) - UFSC.

\section{REFERENCES}

ARCHER, C. L. \& CALDEIRA, K. 2008. Historical trends in the jet streams. Geophysical Research Letters, 35, 1-6.

ARGO. 2000. Argo float data and metadata from Global Data Assembly Centre (Argo GDAC), SEANOE.

ARGO DATA MANAGEMENT TEAM. 2017. Argo User's Manual. v.3.2, IFREMER.

BELKIN, I. M. \& GORDON, A. L. 1996. Southern Ocean fronts from the Greenwich meridian to Tasmania. Journal of Geophysical Research, 101, 3675-3696.
BELKIN, I. M. \& O'REILLY, J. E. 2009. An algorithm for oceanic front detection in chlorophyll and SST satellite imagery. Journal of Marine Systems, 78, 319-326.

BENESTY, J., CHEN, J., HUANG, Y., \& COHEN, I. 2009. Pearson Correlation Coefficient. In: BENESTY, J., CHEN, J., HUANG, Y., \& COHEN, I. Noise Reduction in Speech Processing. Springer: Berlin, Heidelberg.

BLUESTEIN, H. B., 1993. Synoptic Dynamic Meteorology in Midlatitudes. Observations and Theory of Weather Systems. Oxford, Oxford University Press.

BRACEWELL, R. N. 1966. The Fourier transform and its applications. American Journal of Physics, 34, 712-712.

CARLETON, A. M. 1979. A Synoptic Climatology of Satelliteobserved extratropical cyclone activity for the Southern Hemisphere winter. Archiv Für Meteorologie Geophysik und Bioklimatologie Serie B, 279, 265-279.

CHAPMAN, C. C. 2014. Southern Ocean jets and how to find them: Improving and comparing common jet detection methods. Journal of Geophysical Research: Oceans, 119, 43184339.

CHATTERJEE, S., HADI, A. \& PRICE, B. 2000. Regression Analysis by Example, New York, Wiley VCH.

CHURCH, J. A. \& WHITE, N. J. 2011. Sea-Level Rise from the Late 19th to the Early 21st Century. Surveys in Geophysics, 32, 585-602.

CMEMS (Copernicus Marine Environment Monitoring System) 2018. Product user manual. V.4.

CUNNINGHAM, S. A., ALDERSON, S. G., KING, B. A. \& BRANDON, M. A. 2003. Transport and variability of the Antarctic Circumpolar Current in Drake Passage. Journal of Geophysical Research, 108, 1-17.

DE BOER, A. M., GRAHAM, R. M., THOMAS, M. D. \& KOHFELD, K. E. 2013. The control of the Southern Hemisphere Westerlies on the position of the subtropical front. Journal of Geophysical Research: Oceans, 118, 5669-5675.

DEE, D. P., UPPALA, S. M., SIMMONS, A. J., BERRISFORD, P., POLI, P., KOBAYASHI, S., ANDRAE, U., BALMASEDA, M. A., BALSAMO, G., BAUER, P., BECHTOLD, P., BELJAARS, A. C. M., VAN DE BERG, L., BIDLOT, J., BORMANN, N., DELSOL, C., DRAGANI, R., FUENTES, M., GEER, A. J., HAIMBERGER, L., HEALY, S. B., HERSBACH, H., HÓLM, E. V., ISAKSEN, L., KÅLLBERG, P., KÖHLER, M., MATRICARDI, M., MCNALLY, A. P., MONGE-SANZ, B. M., MORCRETTE, J. J., PARK, B. K., PEUBEY, C., DE ROSNAY, P., TAVOLATO, C., THÉPAUT, J. N. \& VITART, F. 2011. The ERA-Interim reanalysis: configuration and performance of the data assimilation system. Quarterly Journal of the Royal Meteorological Society, 137, 553-597.

DONG, S., SPRINTALL, J. \& GILLE, S. T. 2006. Location of the Antarctic Polar Front from AMSR-E Satellite Sea Surface Temperature Measurements. Journal of Physical Oceanography, 36, 2075-2089.

DONOHUE, K. A., TRACEY, K. L., WATTS, D. R., CHIDICHIMO, M. P. \& CHERESKIN, T. K. 2016. Mean Antarctic Circumpolar Current transport measured in Drake Passage. Geophysical Research Letters, 43, 761-767.

DUCHON, C. E. 1979. Lanczos Filtering in One and Two Dimensions. Journal of Applied Meteorology, 18, 1016-1022. 
EICHELBERGER, S. J. \& HARTMANN, D. L. 2007. Zonal jet structure and the leading mode of variability. Journal of Climate, 20, 5149-5163.

EMERY, W. J. 1977. Antarctic polar frontal zone from Australia to the Drake Passage. Journal of Physical Oceanography, 7, 811-822.

ENGLAND, M. H., MCGREGOR, S., SPENCE, P., MEEHL, G. A., TIMMERMANN, A., CAI, W., GUPTA, A. S., MCPHADEN, M. J., PURICH, A. \& SANTOSO, A. 2014. Recent intensification of wind-driven circulation in the Pacific and the ongoing warming hiatus. Nature Climate Change, 4, 222.

FOFONOFF, P. N., \& MILLARD R. JR. 1983. Algorithms for computation of fundamental properties of seawater. Unesco Technical Papers in Marine Sciences, 44, 1-58.

GIGLIO, D. \& JOHNSON, G. C. 2015. Subantarctic and Polar fronts of the Antarctic Circumpolar Current and Southern Ocean heat and freshwater content variability: A view from Argo. Journal of Physical Oceanography, 46, 749-768.

GILL, A. E. 1982. Atmosphere-Ocean Dynamics. Quarter Journal of the Royal Meteorological Society, 110, 280-281.

GILLE, S. T. 2008. Decadal-Scale Temperature Trends in the Southern Hemisphere Ocean. American Meteorological Society, 21, 4749-4765.

GILLE, S. T. 2014. Meridional displacement of the Antarctic Circumpolar Current. Philosophical Transactions of The Royal Society A, 372, 20130273.

GOLUB, G. H. \& REINSCH, C. 1970. Singular Value Decomposition and Least Squares Solutions. Numerische Mathematik, $14,403-420$.

GRAHAM, R. M., DE BOER, A. M., HEYWOOD, K. J., CHAPMAN, M. R. \& STEVENS, D. P. 2012. Southern Ocean fronts: Controlled by wind or topography? Journal of Geophysical Research: Oceans, 117, 1-14.

GRAY, M. W. 1968. Global view of the origin of tropical disturbances and storms. Monthly Weather Review, 96, 669-700.

HANSEN, J., LACIS, A., RIND, D., RUSSELL, G., STONE, P., FUNG, I., RUEDY, R. \& LERNER, J. 1984. Climate sensitivity: Analysis of feedback mechanisms. Climate Processes and Climate Sensitivity, 29, 130-163.

HOLTON, J. R. 1992. An Introduction to Dynamic Meteorology, Burlington, Elsevier Academic Press.

HU, Y. \& FU, Q. 2007. Observed poleward expansion of the Hadley circulation since 1979. Atmospheric Chemistry and Physics, 7, 5229-5236.

HUGHES, L. 2000. Biological consequences of global warming: is the signal already apparent? Trends in Ecology \& Evolution, 15, 56-61.

IHO (International Hidrographic Organization). 1953. Limits of Ocean and Seas. Vol. 28, IHO, Monaco.

KIM, Y. S. \& ORSI, A. H. 2014. On the Variability of Antarctic Circumpolar Current Fronts Inferred from 1992-2011 Altimetry. Journal of Physical Oceanography, 44, 3054-3071.

NAKAMURA, H. \& SHIMPO, A. 2004. Seasonal variations in the Southern Hemisphere storm tracks and jet streams as revealed in a reanalysis dataset. Journal of Climate, 17, 18281844.

O'REILLY, C. H. \& CZAJA, A. 2015. The response of the pacific storm track and atmospheric circulation to kuroshio extension variability. Quarterly Journal of the Royal Meteorological Society, 141, 52-66.
ORSI, H., WHITWORTH, T. \& NOWLIN JR, W. D. 1995. On the meridional extent and fronts of the Antarctic Circumpolar Current. Deep Sea Research Part I: Oceanographic Research Papers, 42, 641-673.

PAOLO, F., S., FRICKER, H. A. \& PADMAN, L. 2015. Volume loss from Antarctic ice shelves is accelerating. Science, 348, 327-331.

POLVANI, L. M., SOBEL, A. H. \& WAUGH, D. W. (eds). 2013. The stratosphere: dynamics, transport, and chemistry, Washington, American Geophysical Union.

POLVANI, L. M., WAUGH, D. W., CORREA, G. J. P. \& SON, S. W. 2011. Stratospheric Ozone Depletion: The Main Driver of Twentieth-Century Atmospheric Circulation Changes in the Southern Hemisphere. American Meteorological Society, 24, 795-812.

PRITCHARD, H. D., LIGTENBERG, S. R. M., FRICKER, H. A., VAUGHAN, D. G., VAN DEN BROEKE, M. R. \& PADMAN, L. 2012. Antarctic ice-sheet loss driven by basal melting of ice shelves. Nature, 484, 502-505.

RANDEL, W. J. \& WU, F. 1999. Cooling of the Arctic and Antarctic Polar Stratospheres due to Ozone Depletion. American Meteorological Society, 12, 1467-1479.

ROEMMICH, D. \& GILSON, J. 2009. The 2004-2008 mean and annual cycle of temperature, salinity, and steric height in the global ocean from the Argo Program. Progress in Oceanography, 82, 81-100.

SALLÉE, J. B., SPEER, K. \& MORROW, R. 2008. Response of the antarctic circumpolar current to atmospheric variability. Journal of Climate, 21, 3020-3039.

SINCLAIR, M. R. 1995. A climatology of Cyclogenesis for the Southern Hemisphere. Monthly Weather Review, 123, 16011619.

SOKOLOV, S. \& RINTOUL, S. R. 2007. Multiple Jets of the Antarctic Circumpolar Current South of Australia. Journal of Physical Oceanography, 37, 1394-1412.

SOKOLOV, S. \& RINTOUL, S. R. 2009a. Circumpolar structure and distribution of the antarctic circumpolar current fronts: 2 . Variability and relationship to sea surface height. Journal of Geophysical Research: Oceans, 114, 1-15.

SOKOLOV, S. \& RINTOUL, S. R. 2009b. Circumpolar structure and distribution of the Antarctic Circumpolar Current fronts: 1. Mean circumpolar paths. Journal of Geophysical Research: Oceans, 114, 1-19.

SUN, C. \& WATTS, D. R. 2002. A view of ACC fronts in streamfunction space. Deep Sea Research Part I: Oceanographic Research Papers, 49, 1141-1164.

SUTTON, P. \& ROEMMICH, D. 2011. Decadal steric and sea surface height changes in the Southern Hemisphere. Geophysical Research Letters, 38, 4-7.

SWART, N. C. \& FYFE, J. C. 2012. Observed and simulated changes in the Southern Hemisphere surface westerly wind-stress. Geophysical Research Letters, 39, L16711.

THOMPSON, A. F. \& SALLEE, J. B. 2012. Jets and topography: jet transitions and the impact on transport in the Antarctic Circumpolar Current. Journal of Physical Oceanography, 42, 956-972.

THOMPSON, D. W. J. \& SOLOMON, S. 2002. Interpretation of Recent Southern Hemisphere Climate Change. Science, 296, 895899. 
TOGGWEILER, J. R. \& RUSSELL, J. L. 2008. Ocean circulation in a warming climate. Nature, 451, 286-288.

TRENBERTH, K. E. 1991. StormTracks in the Southern Hemisphere. Journal of Atmospheric Sciences, 48, 2159-2178.

TRENBERTH, K. E., LARGE, W. G. \& OLSON, J. G. 1990. The Mean Annual Cycle in Global Ocean Wind Stress. Journal of Physical Oceanography, 20, 1742-1760.

TRENBERTH, K. E. \& STEPANIAK, D. P. 2001. Indices of El Nino Evolution. Journal of Climate, 14, 1697-1701.

TRULL, T., RINTOUL, S. R., HADFIELD, M. \& ABRAHAM, E. R. 2001. Circulation and seasonal evolution of polar waters south of Australia: Implications for iron fertilization of the Southern Ocean. Deep-Sea Research Part II: Topical Studies in Oceanography, 48, 2439-2466.
VECCHI, G. A. \& SODEN, B. J. 2007. Increased tropical Atlantic wind shear in model projections of global warming. Geophysical Research Letters, 34, L08702.

WHITWORTH, T., NOWLIN JR, W. D. \& WORLEY, S. J. 1982. The net transport of the Antarctic Circumpolar Current through Drake Passage. Journal of Physical Oceanography, 12, 960-971.

WOOLLINGS, T., HANNACHI, A. \& HOSKINS, B. 2010. Variability of the North Atlantic eddy-driven jet stream. Quarterly Journal of the Royal Meteorological Society, 136, 856868. 